\title{
Frequency of Hepatitis Delta Virus in Hepatitis B Surface- antigen-positive Patients
}

\author{
Hepatit B Yüzey Antijeni-pozitif Hastalarda Hepatit Delta Virüsünün Sıklığı
}

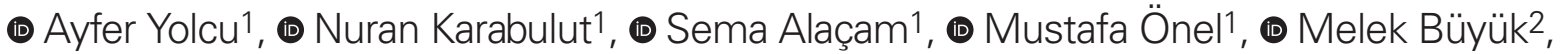 \\ ๑ Mine Güllüoğlu², ๑ Ali Ağaçfidan¹ \\ ${ }^{1}$ Istanbul University, Istanbul Faculty of Medicine, Department of Medical Microbiology, Division of Virology and Fundamental Immunology, Istanbul, Turkey \\ 2Istanbul University, Istanbul Faculty of Medicine, Department of Pathology, Istanbul, Turkey
}

\begin{abstract}
Objectives: The prevalence of hepatitis delta virus (HDV) worldwide shows geographical differences. Although there are several studies on anti-HDV seroprevalence rates in hepatitis B surface antigen (HBsAg)-positive patients in Turkey, studies on HDV-RNA prevalence in this patient population are limited. It was aimed to detect the frequency of anti-HDV antibodies and HDV-RNA in HBsAg-positive patients in this study.

Materials and Methods: This retrospective study included 2089 HBsAg-positive patients in whom anti-HDV was analyzed between April 2015 and March 2017. Anti-HDV test was performed in serum samples obtained from HBsAg-positive patients by enzyme-linked immunosorbent assay. In anti-HDV-positive patients, HDV-RNA was analyzed in serum samples by real-time polymerase chain reaction. Results: The seroprevalence of anti-HDV was 4.1\% (85/2089), while the rate of HDV-RNA positivity was $2.4 \%$ (51/2089). HDVRNA was detected in $60 \%$ (51/85) of anti-HDV-positive patients. The frequency of anti-HDV and HDV-RNA was highest in the 50-59 age group.

Conclusion: The frequency of HDV in this study was found to be consistent with regional data. HDV viremia was detected in only $60 \%(51 / 85)$ of the anti-HDV-positive patients. Since anti-HDV antibodies may remain after recovery, it is important to investigate HDV-RNA to determine the true prevalence of HDV.

Keywords: Hepatitis delta virus, anti-HDV, HDV-RNA, HBV
\end{abstract}

ÖZ

Amaç: Dünya genelinde hepatit delta virüsünün (HDV) yaygınlığı coğrafi farklılıklar göstermektedir. Her ne kadar Türkiye'de hepatit B yüzey antijeni (HBsAg) pozitif olan hastalarda anti-HDV seroprevalans oranları konusunda birçok çalışma olmasına rağmen, bu hasta popülasyonunda HDV-RNA prevalansı ile ilgili çalışmalar sınırlıdır. Bu çalışmada HBsAg pozitif olan hastalarda anti-HDV antikorları ve HDVRNA sıklı̆̆ının saptanması amaçlandı.

Gereç ve Yöntemler: Bu retrospektif çalışma, Nisan 2015 ve Mart 2017 tarihleri arasında HBsAg-pozitif hastalarda anti-HDV testi çalışılan 2089 hastayı kapsadı. HBsAg-pozitif hastalardan alınan serum örneklerinde anti-HDV testi, enzim bağlı immünosorbent metod kullanılarak yapıldı. Anti-HDV-pozitif hastalarda, HDV-RNA, gerçek zamanlı polimeraz zincir reaksiyonu ile serum örneklerinde analiz edildi.

Bulgular: Anti-HDV seroprevalansı \%4,1 (85/2089) iken HDV-RNA oranı \%2,4 (51/2089) idi. HDV-RNA, anti-HDV pozitif olan hastaların \%60'ında (51/85) tespit edildi. Anti-HDV ve HDV-RNA sıklığı 50-59 yaş grubunda en yüksekti.

Sonuç: Bu çalışmada HDV sıklığı bölgesel verilerle tutarlı bulundu. HDV viremisi, anti-HDV pozitif olan hastaların sadece \%60'ında (51/85) tespit edildi. Anti-HDV antikorları iyileşmeden sonra da pozitif kalabileceğinden dolayı, HDV'nin gerçek prevalansını belirlemek için HDV-RNA'nın araştırılması önemlidir.

Anahtar Kelimeler: Hepatit delta virüs, anti-HDV, HDV-RNA, HBV

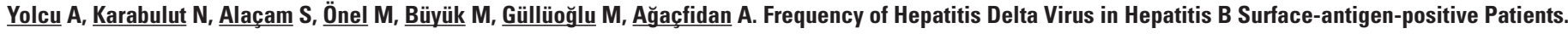
2019;25:14-18.

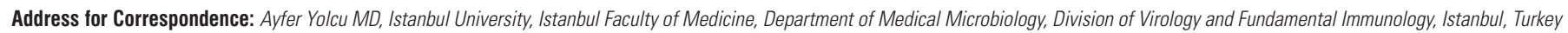
Phone: +90 5466272018 E-mail: dr.ayfer.bakir@gmail.com ORCID ID: orcid.org/0000-0002-9006-5267 Received: 07.08.2018 Accepted: 09.02.2019

${ }^{\circ}$ Copyright 2019 by Viral Hepatitis Society / Viral Hepatitis Journal published by Galenos Publishing House. 


\section{Introduction}

Hepatitis delta virus (HDV), only affects patients with hepatitis B virus (HBV) infection, is a defective hepatotropic virus, as it requires hepatitis B surface antigen (HBsAg) to gain entry into the cell (1). HDV, first discovered in 1977 by Mario Rizetto, is RNA virus with a negative polarity single-stranded circular genome (2). According to the International Committee on Taxonomy of Viruses, HDV is classified in the genus delta virus (3).

The routes of transmission of HDV are similar to those of HBV. It can be transmitted via blood transfusion, intravenous drug use, sexual contact, sharing personal care items, and nosocomial routes. It has been reported that this infection can be transmitted among family members in countries with a high viral prevalence. In addition, intravenous drug use is important in the transmission of HDV in Northern Europe and in countries where HDV prevalence is low $(4,5)$. Globally, countries are classified for asymptomatic HBV carriers as very low endemicity areas for HDV rates of $0-2 \%$, low for $3-9 \%$, medium for $10-19 \%$, and high endemic areas for $>20 \%$; while in chronic HBV-infected patients, it is classified as for $<1 \%$, $3-9 \%, 30-60 \%$, and $>60 \%$, respectively. Turkey is considered a medium endemic area for HDV infection with regional differences $(6,7)$.

HDV infection occurs always in association with hepatitis B infection because of HBV dependence of HDV. The clinical course of HDV infection varies from acute self-limiting infections to fulminant hepatitis. Chronic liver infection can cause end-stage liver disease-related complications such as rapid progression of fibrosis, hepatic decompensation, and hepatocellular carcinoma (1). Simultaneous occurrence of HBV and HDV infections is considered coinfection, while the subsequent HDV infection in a HBsAgpositive person is named as superinfection (8). Chronicity rate in coinfection and superinfection is $2-20 \%$ and $90 \%$, respectively (9).

Detection of anti-HDV total, immunoglobulin (lg) G or lgM antibodies in serum or plasma, HDV antigen in serum, liver biopsy and molecular methods are used for the diagnosis of HDV infection. Anti-HDV positivity does not always reflect the presence of active HDV infection. Detection of HDV-RNA is the most sensitive method for assessing active HDV infection (10).

Studies on HDV-RNA are limited, while there are many antiHDV seroprevalence studies in HBsAg-positive patients in Turkey. Thus, it was aimed to detect the frequency of anti-HDV and HDVRNA in HBsAg-positive patients in a reference university hospital in Istanbul, Turkey.

\section{Materials and Methods}

This retrospective study included $2089 \mathrm{HBs} A g$-positive patients who were analyzed for anti-HDV between April 2015 and March 2017 at the Istanbul University, Istanbul Faculty of Medicine, Department of Medical Microbiology, Division of Virology and Fundamental Immunology, Istanbul, Turkey. This study was approved by the Ethics Committee of Istanbul University, Istanbul Faculty of Medicine (approval number: 2017/651/11). This study was carried out in accordance with the principles of the Helsinki Declaration.

Anti-HDV and HBsAg tests were studied in serum samples using micro-ELISA kits (Dia. Pro, Diagnostic Bioprobes, Milano,
Italy) on a Triturus analyzer (Grifols, Parets del Valles, Spain). The positive and negative control samples were included in each run. Extraction of HDV-RNA was performed using a High Pure Viral Nucleic Acid Kit (Roche Applied Science, Basel, Switzerland) or EZ1 virus mini kit V2 (Qiagen, Germany). Extraction of HBV-DNA was performed using the QIAamp DNA Blood Mini Kit (Qiagen, Germany) according to the manufacturer's recommendations. HDV-RNA is firstly transcribed into cDNA using the transcriptor first strand cDNA synthesis V6 kit (Roche Diagnostics, Mannheim, Germany), and then cDNA was amplified on LightCycler 2.0 realtime polymerase chain reaction (PCR) (Roche Diagnostics $\mathrm{GmbH}$, Switzerland) or Rotor-Gene Q (Qiagen, Germany). HBV-DNA was amplified by real-time PCR on Rotor-Gene Q (Qiagen, Germany).

Biopsy results of only 37 anti-HDV-positive patients could be included in this study between April 2015 and March 2017. The histological activity index and fibrosis were assessed by the modified Knodell scoring system.

\section{Statistical Analysis}

SPSS 21 software (SPSS Inc., Chicago, IL, USA) was used for statistical analysis. The suitability of the variables to the normal distribution was examined via visual methods (histogram and probability plots) and the Kolmogorov-Smirnov test. Difference in mean age between the genders was analyzed using the MannWhitney- $U$ test, and the frequency of HDV-RNA positivity was compared between age groups and genders by the Pearson's chisquare test. A p value of less than 0.05 was considered statistically significant.

\section{Results}

Of the 2089 patients in this study, 1180 (56.5\%) were male and 909 (43.5\%) were female. The mean age of the patients was $46.3 \pm 15.3$ years (1-97). The mean age of male and female patients was $46.3 \pm 15.3$ and $46.4 \pm 15.2$ years, respectively. There was no statistically significant difference in mean age between genders $(p=0.79)$. The frequency of anti-HDV positivity in all patients was $4.1 \%$ (85/2089). Of the anti-HDV positive patients, 42 (49\%) were male and $43(51 \%)$ were female and there was no difference in anti-HDV positivity between genders $(p=0.18)$. The mean age of the anti-HDV-positive patients was $49.5 \pm 11.1$ years. When the distribution of anti-HDV-positive patients with respect to age groups was examined, a significant increase was found in the $50-59$ years age group $(p=0.02)$ (Figure 1$)$.

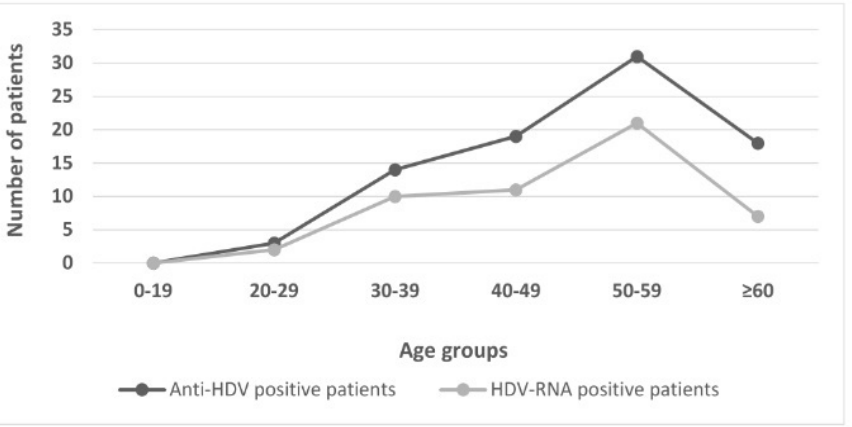

Figure 1. Distribution of anti-HDV and HDV-RNA positive patients according to age

HDV: Hepatitis delta virus 
HDV-RNA was detected in 51 of 85 anti-HDV-positive patients. The frequency of HDV-RNA positivity was $2.4 \%$ (51/2089). The mean age of the HDV-RNA-positive patients was $48.7 \pm 11.5$ years. Of the HDV-RNA-positive patients, 27 (53\%) were male and 24 (47\%) were female. There was no difference in HDV-RNA positivity between the genders $(p=0.41)$. When the distribution of the HDVRNA-positive patients was examined according to age groups, it was observed that the number of patients was highest in the 50-59 age group, but the difference was not statistically significant $(p=0.23)$. The demographic and laboratory characteristics of the HDV-RNA-positive patients were shown in Table 1. Median HBVDNA viral load $(20 \mathrm{lU} / \mathrm{mL})$ in HDV-RNA-positive patients was lower than in HDV-RNA-negative patients $(62 \mathrm{IU} / \mathrm{mL})$, but no statistically significant difference was found $(p=0.09)$.

Table 1. The demographic and laboratory characteristics of patients with hepatitis delta virus-RNA positive

\begin{tabular}{|l|l|l|}
\hline & & $\begin{array}{l}\text { HDV-RNA positive } \\
\text { patients ( } \mathbf{n}=51)\end{array}$ \\
\hline $\begin{array}{l}\text { Age (years) (mean } \pm \\
\text { Standard deviation) }\end{array}$ & $48.7 \pm 11.5$ \\
\hline Gender $\mathrm{n}$ (\%) & Female & 24 (47\%) \\
\hline $\begin{array}{l}\text { HDV-RNA viral load } \\
\text { (Copy/mL) (median) }\end{array}$ & Male & 27 (53\%) \\
\hline $\begin{array}{l}\text { HBV-DNA viral load } \\
\text { (IU/mL) (median) }\end{array}$ & $\begin{array}{l}39200 \\
\text { (IQR: 1250-356476) }\end{array}$ \\
\hline HBV-DNA (n) & Positive & 20 (IQR: 20-45) \\
\hline & Negative & 23 \\
\hline $\begin{array}{l}\text { Liver biopsy* } \\
\text { Fibrosis score } \\
\text { (0-6) (median) }\end{array}$ & 3 \\
\hline $\begin{array}{l}\text { *The liver biopsy was evaluated by Modified Knodell scores } \\
\text { HDV: Hepatitis delta virus, IQR: Interquartile range, (range between the 25 } \\
\text { 75 th }\end{array}$ & $\begin{array}{l}\text { Hercentiles), HBV: Hepatitis B virus } \\
\text { activity index } \\
\text { (2-16) (median) }\end{array}$ & 8 \\
\hline
\end{tabular}

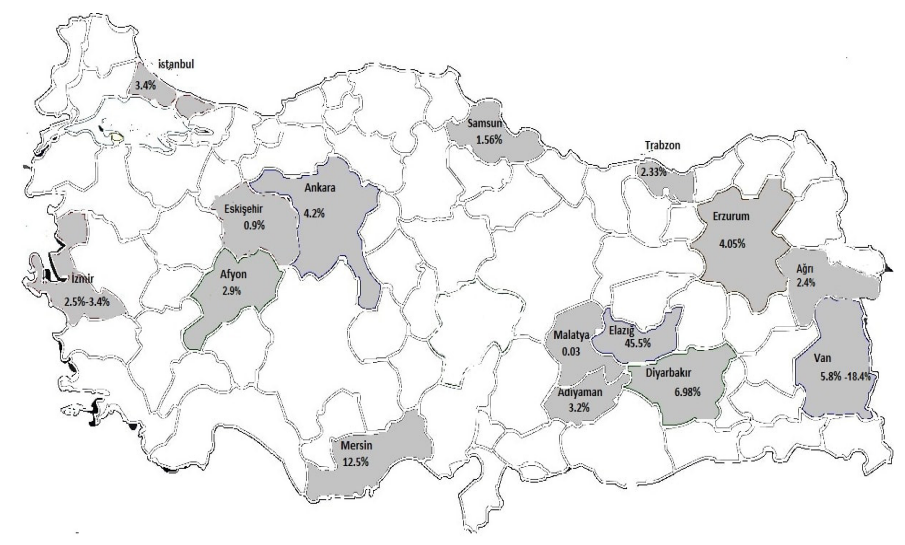

Figure 2. Anti-HDV seroprevalance in several areas of Turkey

\section{Discussion}

Despite the widespread application of HBV vaccine, HDV infection continues to be a global health problem, even in some developed countries, including some European countries, the US and Australia (1). The World Health Organization reported that there were globally 240 million people chronically infected with HBV, and about 15 million individuals chronically infected with both HDV and HBV. Globally, it is estimated that $5 \%$ of HBsAg-positive people are coinfected with HDV (11). Epidemiological studies indicate that the rate of anti-HDV positivity is lower in the Far Eastern countries with high HBV endemicity and higher in the Mediterranean countries with moderate HBV endemicity (12). As in the world, HDV frequency also shows regional differences in Turkey (Figure 2) $(12,13,14,15,16,17,18,19,20,21,22,23,24,25,26,27,28)$. Higher rates were reported in the Eastern and Southeastern Anatolian regions. Regional studies on seroprevalence of anti-HDV in Turkey showed a rate of $2.5 \%$ to $3.4 \%$ in the Western Anatolia region, $0.9 \%$ to $15 \%$ in the Central Anatolia region, $0.3 \%$ to $45.5 \%$ in the Eastern Anatolia region and $3.2 \%$ to $6.98 \%$ in the Southeastern Anatolia region. The reported rate of anti-HDV seroprevalence in studies performed in Turkey varies between $0.3 \%$ and $45.5 \%$ showing regional differences $(21,28)$. In a study conducted in Istanbul, the frequency of anti-HDV positivity in patients with chronic HBV infections was 3.4\% (46/1339) (13). There are limited studies on the prevalence of HDV in Istanbul. In this study, anti-HDV seroprevalence was found to be $4.1 \%$ (85/2089) and HDV-RNA positivity was $2.4 \%(51 / 2089)$ in $2089 \mathrm{HBsAg}$ positive patients. The cause of detection of lower rates of HDV-RNA compared to anti-HDV may be related to the fact that anti-HDV antibodies may remain after recovery.

There are a limited number of HDV-RNA studies reflecting the true HDV prevalence in Turkey. The frequency rate of HDVRNA positivity in $547 \mathrm{HBsAg-positive} \mathrm{patients} \mathrm{was} \mathrm{found} \mathrm{to} \mathrm{be}$ $0.9 \%$ in a study conducted in the Central Anatolia, Turkey (17). In the Western region of Turkey, the rate of HDV-RNA positivity in 88 patients was found to be $2.3 \%$ (13). In a study conducted in 180 patients in Southeastern Anatolia, HDV-RNA positivity was detected in only two patients (27). In their study including 282 patients performed in Eastern Anatolia, Bahcecioglu et al. (28) reported that $23.4 \%$ of the subjects were HDV-RNA-positive. In this study, the frequency of HDV-RNA positivity was $2.4 \%$ (51/2089). Immunization with hepatitis B vaccine and the exclusion of highrisk blood donors before blood donation may be associated with low prevalence rates. High prevalence rates may be related to the fact that the studies were conducted in regions where HBV is high endemic and in patients with chronic HBV infection.

In a study performed in Romania, anti-HDV positivity was found in 223 (20.4\%) of 1094 patients with chronic HB infection. Hepatitis D viremia was detected in $67.7 \%$ of these patients (29). In another study conducted in Romania, anti-HDV IgG seroprevalence was found $23.1 \%$ in $2761 \mathrm{HBsAg}$-positive patients, whereas HDV-RNA was positive in $16.4 \%$ of these patients (30). The rate of anti-HDV seroprevalence was reported as $7.7 \%$ in 169 chronic HBV cases in Saudi Arabia, whereas only four patients were HDV-RNA-positive (31). HDV-RNA is an important parameter for determining the true HDV prevalence, because anti-HDV may remain positive for many years after infection, or antibodies against HDV infection may not 
be detected in the window period. In this study, the anti-HDV positivity rate was $4.1 \%$ and the HDV-RNA positivity rate was $2.4 \%$ in $2089 \mathrm{HBsAg-positive} \mathrm{patients.} \mathrm{In} \mathrm{Turkey,} \mathrm{although} \mathrm{the} \mathrm{rates}$ have decreased in the Western Anatolia region, the prevalence of HDV infection is still at high levels in the Eastern Anatolia region. However, the decline in these rates may be related to sociocultural and socio-economic improvements, good laboratory practices in the screening of blood and blood products.

Long-term studies have shown a decrease in HDV seroprevalence in some endemic regions. Infection rates have decreased especially in young patients. HDV infections in Italy have been reported to be limited to those infected around the 1980s. As well as improvements in socio-economic and hygiene conditions, media campaigns for mass vaccination programs are thought to play a role in this decline in incidence rates in Italy (32). It has been reported that there was also a decrease in prevalence rates in Spain, India, Taiwan and Turkey $(33,34,35)$.

In the present study, the mean age of the anti-HDV-positive patients was $49.5 \pm 11.1$ years, and a significant increase in anti-HDV positivity was detected in the 50-59 age group. Similar results were found in studies conducted in our country $(14,36)$. Unlike this study, in a study conducted in the UK, the median age of 82 anti-HDVpositive patients was 36 years. The low median age was thought to be related to migration from endemic regions and intravenous drug use (37). In another study examining the anti-HDV seroprevalence in 362 patients aged between 4 and 70 in Pakistan, 212 patients $(58.6 \%)$ with a mean age of $29.75 \pm 11.27$ years were found to be anti-HDV-positive. The higher rates of anti-HDV positivity in young adults were thought to be associated with injectable drug abuse and the use contaminated needles for therapeutic injections in this age group (38). Sexual transmission may be another possible route that leads to these higher prevalence rates (38). In this study, high anti-HDV positivity rates in older ages may be related to the vaccination program implemented in Turkey for more than 20 years and the family screening programs for patients with hepatitis $B$.

This study has some limitations; due to its retrospective design, the clinical data of the patients and data regarding the clinical course of HBV infection could not be obtained.

\section{Conclusion}

The anti-HDV rates detected in this study were consistent with regional data in Turkey, but lower than in studies conducted in the Eastern region of the country. In addition, HDV viremia was detected in only 60\% (51/85) of anti-HDV-positive patients. It is important to investigate HDV-RNA to determine the true prevalence of HDV because anti-HDV antibodies may remain after recovery.

Acknowledgements: The authors thank for the technical assistance of Ümit Çetin.

\section{Ethics}

Ethics Committee Approval: This study was approved by the Ethics Committee of Istanbul University, Istanbul Faculty of Medicine (approval number: 2017/651/11).

Informed Consent: Retrospective study.

Peer-review: Externally peer-reviewed.

\section{Authorship Contributions}

Concept: A.Y., Design: A.Y., N.K., S.A., A.A., Data Collection or Processing: A.Y., N.K., S.A., M.Ö., M.B., M.G., A.A., Analysis or Interpretation: A.Y., N.K., Literature Search: A.Y., S.A., Writing: A.Y., N.K., S.A.

Conflict of Interest: No conflict of interest was declared by the author.

Financial Disclosure: The authors declared that this study received no financial support.

\section{References}

1. Sultanik P, Pol S. Hepatitis delta virus: Epidemiology, natural course and treatment. J Infect Dis Ther. 2016;4:271.

2. Botelho-Souza LF, Vasconcelos MPA, dos Santos AO, Salcedo JMV, Vieira DS. Hepatitis delta: virological and clinical aspects. Virol J. $2017 ; 14: 177$

3. ICTV. 9th Report (2011). Virus Taxonomy: 2017 Release. Delta virus (08.03.2018). Availablefrom: https://talk.ictvonline.org/ ictv-reports/ictv_9 th_report/negative-sense-rna-viruses-2011/w/ negrna_viruses/211/deltavirus.

4. Tahaei SM, Mohebbi SR, Azimzadeh P, Behelgardi A, Sanati A, Mohammadi P, Khanyaghma M, Hosseini Razavi A, Sharifian A, Zali MR. Prevalence of hepatitis $D$ virus in hepatitis $B$ virus infected patients referred to Taleghani hospital, Tehran, Iran. Gastroenterol Hepatol Bed Bench. 2014;7:144-150.

5. Doğan M, Günes H, Mete R, Taș T, Mengeloğlu FZ, Küçükbayrak A. Prevalence of anti-HDV and HDAg in patients with chronic hepatitis B. Dicle Med J. 2013;40:50-53

6. Celen MK, Kandemir O. Hepatit delta virüsü enfeksiyonunun epidemiyolojisi. Içinde: Kandemir O, Danalıoglu A, editörler. Hepatit B'den D'ye hepatit güncel klinik el kitabı. Istanbul: Viral Hepatitle Savaşım Derneği; 2015;p.267-271.

7. Kemal Celen M, Tekin Koruk S, Aygen B, Dal T, Karabay O, Tosun S, Koksal I, Turgut H, Onlen Y, Balik I, Yildirim N, Sinan Dal M, Ayaz C. Tabak F. The characteristics of patients with chronic hepatitis B in Turkey. Med Glas (Zenica). 2014;11:94-98.

8. Yalcın K, Tuncel ET, Gunduz F. Latest updates on chronic delta hepatitis. Marmara Medical Journal. 2016;29:50-54.

9. Noureddin M, Gish R. Hepatitis delta: epidemiology, diagnosis and management 36 years after discovery. Curr Gastroenterol Rep. 2014;16:365

10. Olivero A, Smedile A. Hepatitis delta virus diagnosis. Semin liver dis. 2012;220-227.

11. WHO. Hepatitis D Fact Sheet (13.10.2017). Available from: http:// www.who.int/mediacentre/factsheets/hepatitis-d/en/.

12. Iskender G, Ogan MC, Saylır K, Dirim EB, Batı S, Cimentepe M, Yenigun A. Seroprevalerıce of anti-HDV antibody in HBsAg positive patients. Acta Oncologica Turcica. 2006;39:99-100.

13. Uzun B, Şener AG, Güngör $S$, Afşar I, Demirci M. Evaluation of hepatitis delta virus (HDV) infection in blood donors in western Turkey. Transfus Apher Sci. 2014;50:388-391.

14. Parlak E, Erturk A, Parlak M, Kosan Z, Albayrak A, Ozkurt Z, Ozden K, Erol S. Assessment of patients with hepatitis D. Viral Hepat J. 2015;21:80-84

15. Kurtoglu MG, Ustun C, Bozkurt H, Tuncer O, Berktas M. Hepatitis $D$ virus seroprevalence determined during periods of hepatitis $B$ virus infections In Eastern Turkey. Viral Hepat J. 2009;14:27-32.

16. Kose S, Ece G, Gozaydin A, Turken M. Study on seroprevalence of hepatitis delta in a regional hospital in Western Turkey. $\mathrm{J}$ Infect Dev Ctries. 2012;6:782-785

17. Korkmaz P, Aykın N, Cevik FC, Guduren HM, Alpay Y. Seropositivity of delta hepatitis in HBsAg positive patients in Eskişehir province. Viral Hepat J. 2014;20:72-74. 
18. Karadag A, YIImaz H, Goren I, Acuner IC, Eroglu C, Gunaydın M. Defining the delta virus positivity in hepatitis $\mathrm{B}$ virus infections. Viral Hepat J. 2014;20:64-66

19. Inci A, Fincanci M, Muderrisoglu C. Investigation of anti-hepatitis delta virus and anti-hepatitis $C$ virus in patients with hepatitis $B$ virus infection/kronik hepatit B'li olgularda anti hepatit delta virüs (anti HDV), anti hepatit C virus (anti-HCV) antikorları sıklığının araștırılması. Istanbul Med J. 2013;14:109-112.

20. Gurkan Y, Toyran A, Aksoy A, Coskun FA, Cetin F. Evaluation of HBsAg and anti-HDV seroprevalance of patients who admitted to Ankara Numune Training and Research Hospital between 20102013. Viral Hepatitis J. 2013;19:148-151.

21. Duman Y, Tekerekoglu MS, Ay S. Seroprevalence of HBsAg, antiHBs, anti-HDV and HDVAg in Inönü University Medical Faculty Hospital, 2012. Med-Science. 2014;3:982-990.

22. Dulger AC, Suvak B, Gonullu H, Gonullu E, Gultepe B, Aydın I, Batur A, Karadas S, Olmez Ş. High prevalence of chronic hepatitis D virus infection in Eastern Turkey: urbanization of the disease. Arch Med Sci. 2016;12:415-420.

23. Doğan $M$, Güneş $H$, Mete $R$, Taş $T$, Mengeloğlu FZ, Küçükbayrak A. Prevalence of anti-HDV and HDAg in patients with chronic hepatitis B. Dicle Med J. 2013;40:50-53.

24. Demirdal T, Demirtürk N, Aşcı Z. Afyonkarahisar ilinde hepatit delta virüsü seroprevalansı. Viral Hepatit Derg. 2009;14:104-107.

25. Kandemir Ö, Ersöz G, Uğuz K, Kaya A. Kronik hepatit B infeksiyonlu hastalarda anti-HDV sıklığı. Viral Hepatit Derg. 2001;1:263-265.

26. Kölgelier S, Demir NA, Özçimen S. Seropositivity of delta hepatitis in HBsAg positive patients in Adıyaman province. Viral Hep J. 2013;19:8-10.

27. Mese S, Nergiz S, Tekes S, Gul K. Seroprevalence of serum HBsAg positivity and hepatitis delta virus infection among blood donors in Southeastern Turkey. Clin Ter. 2014;165:95-98.

28. Bahcecioglu I, Aygun C, Gozel N, Poyrazoglu O, Bulut Y, Yalniz $M$. Prevalence of hepatitis delta virus (HDV) infection in chronic hepatitis B patients in eastern Turkey: still a serious problem to consider. J Viral Hep. 2011;18:518-524.
29. Popescu GA, Otelea D, Gavriliu LC, Neaga E, Popescu C, Paraschiv $S$, Fratila M. Epidemiology of hepatitis $D$ in patients infected with hepatitis B virus in bucharest: A cross sectional study. J Med Virol. 2013;85:769-774.

30. Gheorghe L, Csiki IE, lacob S, Gheorghe C, Trifan A, Grigorescu M, Motoc A, Suceveanu A, Curescu M, Caruntu F, Sporea I, Brisc C, Rogoveanu I, Cerban R, Tugui L, Alexandrescu A. Hepatitis delta virus infection in Romania: prevalence and risk factors. J Gastrointestin Liver Dis. 2015:24:413-421.

31. Jamjoom GA, El-Daly MM, Azhar El, Fallatah HI, Akbar HO, Babatin M, Alghamdi SA, Dgdgi MI, Hamid MA, Qari YA, El-Kafrawy SA. Prevalence and molecular characterization of hepatitis $D$ virus in Saudi Arabia: A single-center study. Saudi J Gastroenterol. 2017;23:176-182.

32. Sagnelli E, Sagnelli C, Pisaturo M, Macera M, Coppola N Epidemiology of acute and chronic hepatitis B and delta over the last 5 decades in Italy. World J Gastroenterol. 2014;20:7635-7643.

33. Hughes SA, Wedemeyer H, Harrison PM. Hepatitis delta virus. Lancet. 2011;378:73-85.

34. Gomaa N, Metwally LA, Nemr N, Younis S. Seroprevalence of HDV infection in HBsAg positive population in Ismailia, Egypt. Egypt $J$ Immunol. 2013;20:23-28.

35. Değertekin $H$, Yalçın K, Yakut M, Yurdaydin C. Seropositivity for delta hepatitis in patients with chronic hepatitis B and liver cirrhosis in Turkey: a meta-analysis. Liver Int. 2008;28:494-498.

36. Yozgat A, Altiparmak E, Demirci S, Caglayan O, Aliyazicioglu M, Koseoglu HT, Erten AT, Cetin F, Uner E, Ozaslan E, Altınbas A. Delta hepatitis frequency in chronic hepatitis B patients: Single center retrospective. Ortadogu Medical Journal. 2015;7:12-15.

37. Cross TJ, Rizzi P, Horner M, Jolly A, Hussain MJ, Smith HM, Vergani $D$, Harrison PM. The increasing prevalence of hepatitis delta virus (HDV) infection in South London. J Med Virol. 2008;80:277-282.

38. Seetlani NK, Abbas Z, Raza S, Yakoob J, Jafri W. Prevalence of hepatitis $D$ in HBsAg positive patients visiting liver clinics. J Pak Med Assoc. 2009;59:434-437. 